Discussion Paper No. 14-053

\title{
A Viable Insolvency Procedure for Sovereigns (VIPS) in the Euro Area
}

Clemens Fuest, Friedrich Heinemann, and Christoph Schröder

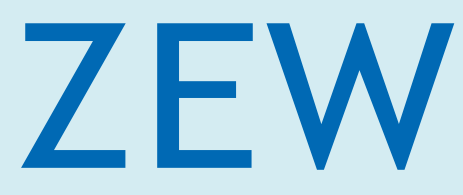

Zentrum für Europäische Wirtschaftsforschung $\mathrm{GmbH}$ Centre for European Economic Research 
Discussion Paper No. 14-053

\title{
A Viable Insolvency Procedure for Sovereigns (VIPS) in the Euro Area
}

\author{
Clemens Fuest, Friedrich Heinemann, \\ and Christoph Schröder
}

Download this ZEW Discussion Paper from our ftp server:

http://ftp.zew.de/pub/zew-docs/dp/dp14053.pdf

Die Discussion Papers dienen einer möglichst schnellen Verbreitung von neueren Forschungsarbeiten des ZEW. Die Beiträge liegen in alleiniger Verantwortung der Autoren und stellen nicht notwendigerweise die Meinung des ZEW dar.

Discussion Papers are intended to make results of ZEW research promptly available to other economists in order to encourage discussion and suggestions for revisions. The authors are solely responsible for the contents which do not necessarily represent the opinion of the ZEW. 


\title{
A Viable Insolvency Procedure for Sovereigns (VIPS) in the Euro Area
}

\author{
Clemens Fuest (ZEW Mannheim and University of Mannheim) \\ Friedrich Heinemann (ZEW Mannheim and University of Heidelberg) \\ Christoph Schröder (ZEW Mannheim)
}

August 2014

\begin{abstract}
:
A mechanism to restructure the debt of an insolvent euro country is a missing element in the emerging institutional architecture of the euro area. The introduction of an insolvency procedure for sovereigns faces a dilemma: In the foreseeable future, its introduction would risk pushing Europe back into acute crisis. But the indefinite postponement of reform would impair the credibility of a future regime change. Against this background, this paper reviews arguments and existing blueprints for sovereign insolvency procedures in the euro area and develops a "Viable Insolvency Procedure for Sovereigns" (VIPS). VIPS avoids any sudden measures which could destabilize the present fragile situation but carefully designs an irreversible transition towards the new regime. The VIPS proposal comprises two pillars: An insolvency procedure for the long run and a credible bridge towards that system.
\end{abstract}

JEL Classification: F34, H12, H63

Keywords: euro area debt crisis, sovereign insolvency procedure

\begin{tabular}{lll} 
Clemens Fuest & $\begin{array}{l}\text { Friedrich Heinemann } \\
\text { Corresponding author }\end{array}$ & Christoph Schröder \\
\cline { 2 - 3 } ZEW Mannheim & ZEW Mannheim & \\
L7, 1 & L7, & ZEW Mannheim \\
68161 Mannheim & 68161 Mannheim & L7, 1 \\
Germany & Germany & 68161 Mannheim \\
fuest@zew.de & heinemann@zew.de & Germany \\
Tel.:+49-621-1235-100 & Tel.:+49-621-1235-149 & christoph.schroeder@zew.de \\
\end{tabular}




\section{Introduction}

The euro area debt crisis has revealed serious flaws in the institutional setup of the European Monetary Union (EMU) as it had been designed in the late 1990s (Buti and Carnot, 2012; Hodson, 2013). Although the establishment of a common currency was a step towards more integration of financial and banking markets, supervision remained national. Although the common currency inherently had increased the fragility of government bond markets for selffulfilling default expectations (De Grauwe and Ji, 2012), no lender of last resort has been identified. And although one member's unsustainable fiscal policy implies high costs for all countries of a currency area, national budgetary decisions had been left effectively unconstrained.

In 2010, the crisis started a wave of sometimes hasty reforms to adjust this deficient setting. The temporary European Financial Stability Facility (EFSF) and the permanent European Stability Mechanism (ESM) are new multilateral loan facilities created with the intention of stabilizing the government bonds market in the euro area (European Central Bank, 2011; Olivares-Caminal, 2011). A key element of this reform program is the development of the banking union. It includes a single supervisory mechanism (Howarth and Quaglia, forthcoming) and bank resolution systems (European Commission, 2014). In addition, the European Central Bank partially assumed responsibility of a lender of last resort in case of government bond market panics and established the Outright Monetary Transaction (OMT) program (European Central Bank, 2012b). EFSF, ESM and OMT all offer liquidity assistance which is conditional on far reaching consolidation and reform efforts undertaken by the debtor. Finally, the feeble and ineffective Stability and Growth Pact was reformed, specified and complemented with national debt brakes, which all euro area member states have accepted by signing the European Fiscal Compact (European Central Bank, 2012a; Burret and Schnellenbach, 2014).

While this reform program is comprehensive, another serious incompleteness strikes: Until today, there is no well-defined and feasible insolvency procedure, which could be applied to restructure the sovereign debt of a euro area member state. This lack of a well-defined insolvency procedure remains a much neglected subject in the emerging new institutional structure of the euro area in at least two respects.

First, the conditionality claim of EFSF, ESM and OMT loans can only be credible, if creditors have a real alternative to keeping a crisis country liquid under any circumstances. As long as the prospect of restructuring remains an unacceptable high-risk scenario any threat to stop loans (EFSF/ESM) or bond purchases (OMT) in case of non-compliance lacks credibility. In this case, public creditors are forced to give fresh money even to an insolvent country and even to a country which does not comply with conditions for help. This line of reasoning leads to a disturbing explanation for the calming of government bond markets in the Eurozone since the establishment of the OMT program in 2012: The decline of yield spreads may be 
partially explained by the expectation that, with the ESM and the OMT, the euro area now has effectively established bailout-institutions for future insolvencies.

Only a credible restructuring prospect can prevent a system, which is intended to merely provide conditional liquidity assistance in the short run and serve as a precaution against selffulfilling crises, from turning into a system of potentially unconditional permanent transfers (Committee on International Economic Policy and Reform, 2013). In this sense, the establishment of an insolvency procedure should not be seen as a minor technical decision. It is a necessary complement to ESM's and ECB's liquidity assistance by preventing this assistance from degenerating into a transfer system. In fact, this issue amounts to nothing less than the constitutional decision on whether the euro area countries form a transfer union based on full bailout-out guarantees or not.

Second and closely related, the prospect of sovereign insolvency is crucial to safeguard market discipline as a complement to rule based fiscal discipline. If the restructuring of single euro area member states' debt is no realistic option, creditors hardly face any default risk when lending money to these borrowers. Governments would then have the privilege of a highly elastic credit supply at interest rates which reflect the creditworthiness of the euro area as a whole. The resulting low risk spreads induce highly indebted countries to run even further into debt because debt, from their perspective, is relatively cheap. Only the realistic possibility of some kind of sovereign default can induce borrowers to carefully examine creditworthiness of euro area countries before buying their bonds. The ongoing establishment of the European Banking Union will further weaken market discipline as it relieves member states of their financial responsibility for the national banking systems and improves their sovereign creditworthiness. Therefore, there is an even growing need to revitalize market discipline through a clear perspective on the possibility of sovereign insolvency.

While there is a strong case for an insolvency procedure for sovereigns in a newly designed EMU setup, its introduction is challenging. The financial and economic situation in the euro area will remain fragile for a considerable period of time as a consequence of the crisis. Although the panic-driven turbulences at the euro area bond markets have receded since 2012 (also due to ECB involvement), there is a permanent risk of sliding back into acute crisis and contagion. Debt-to-GDP ratios have not yet even started to decline in the crisis countries, their growth outlook remains weak and they have only just started to catch up in terms of international competitiveness. ${ }^{1}$ In this situation, the introduction of a detailed and credible insolven-

\footnotetext{
${ }^{1}$ Further risks emanate from current legal uncertainties related to the consistency of the OMT program with EU primary law and a related case at the German Federal Constitutional Court. The German Constitutional Court has submitted the case to the European Court of Justice in January 2014. The German Court raised substantial doubts whether the OMT is covered by the monetary competencies of the ECB (Bundesverfassungsgericht, 2014). A possible outcome could be that limits must be set with respect to the extent of the bond purchasing program,
} 
cy procedure could be seen as a signal for an imminent restructuring, which might trigger a new flight from peripheral government bond markets. Thus, there is an underlying dilemma with respect to the introduction of any sovereign insolvency procedure (Mody, 2013): Calm and stable years would offer ideal conditions to establish transparent restructuring rules. But it is only during acute debt crises that the need for such rules is recognized.

Our proposal of a "Viable Insolvency Procedure for Sovereigns" (VIPS) takes this dilemma seriously. It builds on the existing models (surveyed below) for the euro area but develops them further with a particular focus on the transition problem. It designs a reform path based on lagged implementation which could overcome the dilemma described.

On the one hand, VIPS takes a cautious approach and avoids any sudden measures which could further destabilize the present fragile situation. Full effectiveness of the procedure is delayed until important objectives for the new institutional set-up have been achieved and a more solid market environment (including a stabilized banking system, a functioning banking union, and progress in cutting back public indebtedness) has been created. On the other hand, VIPS comprises immediate decisions and the beginning phasing-in of institutional adjustments which are to make the (later) full introduction of the insolvency procedure irreversible. ${ }^{2}$ Thus, VIPS makes use of the crisis related problem awareness and reform momentum to initiate a far reaching institutional innovation but tries to minimize the risks in the immediate aftermath of the crisis. In addition, delayed implementation may allow countries to at least partially abstract from their own narrow interests.

In the next section we will discuss why, under the specific conditions of EMU, a well-defined insolvency procedure is preferable to flexible ad hoc solutions. Subsequently, we review existing models for sovereign insolvency procedures with a focus on those developed for the euro area. Section 4 describes VIPS' long-run elements and section 5 its transition path, followed by a conclusion in section 6 .

\footnotetext{
which could raise doubts in the markets that the ECB can be an effective lender of last resort for euro area governments.

${ }^{2}$ Renegotiation can of course never be ruled out but reversing an agreement on the introduction of an insolvency procedure under conditions specified today would at least be difficult since a later change of the ESM Treaty would require an unanimous decision. Single countries could decide unilaterally to leave the ESM Treaty but this would cut them off any potential ESM loans.
} 


\section{Ad hoc solutions versus pre-defined procedures}

The history of public debt (Reinhart and Rogoff, 2008) and the more recent experience with the European debt crisis clearly showed that sovereign countries may end up in a situation of insolvency. ${ }^{3}$ There are two essentially different ways to deal with fundamentally insolvent members of the euro area: ${ }^{4}$ Either a bailout is organized through (open or hidden) transfers from other euro area members or debt has to be restructured. So far EU law has explicitly excluded bailouts but, at the same time, has shown no explicit interest in other options. Negating a transfers-solution without offering a perspective on debt restructuring is a major inconsistency in the institutional framework of the euro area.

However, although the restructuring of public debt is not explicitly mentioned in EU law, it is not forbidden either. In fact, in the case of Greece in 2012, there was a substantial private sector involvement (PSI) (Zettelmeyer, Trebesch and Gulati, 2013). The Greek experience demonstrates that the restructuring option actually is available. However, there is no welldefined procedure. Hence, the question emerges whether the euro area needs detailed institutional solutions to arrange future restructurings or whether it is sufficient to rely on ad hoc solutions.

Opponents to statutory insolvency procedures argue that an insolvency procedure would unduly limit market participants. Creditors and sovereign debtors would have incentives to jointly find a suitable solution, which would take account of the individual characteristics of each single case (Gianviti et al., 2010). According to this view, the recommendation of nonbinding „Codes of Good Conduct“ for creditors and borrowers or an agreement on collective action clauses (CAC) in bond contracts should be sufficient. However, solely relying on ad hoc solutions brings about challenges, which the proponents of euro area insolvency procedures stress (see for similar reasoning Gianviti et al., 2010; Committee on International Economic Policy and Reform, 2013; Mody, 2013):

Nowadays, public debt is predominantly financed through bonds which are held by a large number of very diverse and dispersed investors. This makes ad hoc-negotiations between the borrower and the numerous creditors difficult and time consuming. Collective-actionproblems are notorious in this context. A first problem of that kind is related to the downward dynamics in an acute debt crisis: Without an insolvency procedure which equates losses for

\footnotetext{
${ }^{3}$ If one accepts the notion that multiple equilibria can drive solvent countries into illiquidity this insight does not negate the possibility of fundamental insolvency. However, the empirical distinction between illiquidity in a "bad" equilibrium and fundamental insolvency is difficult in reality. An insolvency procedure has to deal with this difficulty. VIPS takes account of this challenge through its "shelter period", see section 4.

${ }^{4}$ In principle, there are further available options: generating a surprise inflation which erodes the real value of debt or "financial repression" through privileged or forced access of governments to private savings. We assume that these solutions are neither available nor desirable options for the euro area. Actually, the price stability objective and the ban of privileged government market access in the EU Treaty limit these exits from public debt.
} 
all creditors (and hence equates ex ante-risks for investors), there is a detrimental first mover advantage. It pays off to "rush to the exit" (Roubini and Setser, 2004). By contrast, a defined procedure offers the prospect that, in case of illiquidity, rules will ensure equal treatment of creditors. This prospect can be a stabilizing factor in itself.

Pre-defined procedures can also address a second collective-action-problem: In ad hocnegotiations, single creditors have an incentive to refuse a debt settlement (holdout-problem) and to insist on full repayment through litigation, which in turn decreases the willingness and thus the probability of all other creditors to accept the debt exchange. In the case of Argentina, the holdout-strategy of specialized vulture funds recently proved to be successful once again since US courts decided in their favour (Committee on International Economic Policy and Reform, 2013, Chapter 3). This current experience further encourages the existing disincentives to accept a restructuring offer. The underlying coordination problem creates uncertainties and delays, resulting in further increasing indebtedness and unnecessary crisis escalations characterized by dwindling reserves, capital flight and output losses (Krueger, 2002; International Monetary Fund, 2013). Compared to an ad hoc approach, a properly designed insolvency regime can reduce the chances of holdout-strategies. It can shorten the duration of negotiations and it also may reduce other costs since "markets prefer the certainty of debt restructuring to the uncertainty of an ad hoc process with no imminent resolution of the underlying debt problem” (Mody, 2013: 16).

CACs, which state that a qualified majority of bond holders can take decisions binding for all bond holders, may alleviate but not necessarily solve these collective-action-problems entirely. Conventional CACs can only constrain holders of one single bond issue but not all debtors of one country. Holdout-strategists can buy majorities (or blocking minorities) of single bond issues and litigate for full repayment. Even if that problem can be tackled through aggregation clauses in CACs, these clauses do not offer any hint as to the trigger of restructuring, the time perspective of negotiations, the expected loss in case these clauses were to be used or ways of interim financing during negotiations. In sum, improved CACs may be a reasonable complement to a full insolvency procedure but they are certainly no substitute.

Finally, a statutory insolvency procedure would also reduce uncertainty regarding payment moratoria during the time of negotiations and the extent of financial assistance as well as its conditionality. Both creditors and debtors would profit from the reduction of this type of uncertainty because the debtor country could not sell or destroy asset values as long as the negotiations are under way and the creditor would be fully informed about potential financial assistance and its conditions - information that is highly relevant for the negotiations and the related decision-making of investors.

While the aforementioned aspects apply to any regional context with a large number of creditors, the specific circumstances and recent experiences of the euro area strengthen the case for a defined procedure even more. The lack of any provisions to deal with sovereign insolvency 
created massive uncertainties for Greece's creditors in 2009/2010. The Greek insolvency became obvious in 2010. At that time, bond holders had no information about applicable procedures, the realistic final loss in case of a Greek default or the time perspective for a settlement. This uncertainty created a massive rush to the exit with immediate contagion to other country segments in the euro area government bond markets.

The fact that a PSI was eventually achieved for Greece in 2012 does hardly point towards the merits of ad hoc negotiations (Zettelmeyer, Trebesch und Gulati, 2013). The long delay between the point in time that Greece lost its bond market access and the implementation of the PSI was effectively financed by taxpayers in other euro countries. Maturing Greek bonds and the continuing primary deficit were covered by the new European loan facilities (bilateral loans from euro area partners and loans from the European Financial Stability Facility). The long lasting uncertainties about a sustainable Greek debt settlement added to the dramatic and persistent decline of the real economy. Furthermore, the Greek PSI constitutes a precedent which has even aggravated the collective-action-problems for future euro area cases: Majority holders of single Greek bonds who refused to participate in the PSI have been treated generously and achieved full repayment.

Apart from the Greek experience, general features of the euro area underline the need for well-defined procedures (Gianviti et al., 2010). European conditions are characterized by high real and financial integration of national economies, very high public debt levels (relative to world GDP) and a particular investor structure (with a heavy involvement of euro area financial institutions). All these features increase both the risks and complexities of any attempts of ad hoc restructurings. Therefore, relatively favourable experiences with ad hoc negotiations in the cases of insolvent developing or emerging economies (Das, Papaioannou and Trebesch, 2012) hardly deliver relevant information for the euro area.

One of the opponents' political arguments against a global insolvency procedure like the Sovereign Debt Restructuring Mechanism (SDRM, see below) is the decisive role of multilateral institutions like the IMF and the implied reduction of national autonomy. Such arguments are significantly less relevant in the institutional context of the European Union and the euro area (Gianviti et al., 2010). In the ongoing process of integration, member countries have already transferred substantial sovereignty to the European level. As a reaction to the debt crisis, they have accepted several new and far reaching constraints on fiscal policy, a European approach to banking and financial market supervision, and have established mutual loan facilities based on strict conditionality. At this advanced stage of integration, it can hardly be a problem in itself, that a European institution plays a prominent role in an insolvency procedure. 


\section{Survey of proposals for sovereign insolvency procedures}

The design of insolvency procedures is rooted in the proposals of statutory restructuring procedures for developing countries, which have been put forward since the 1980s (for surveys see e.g. Rogoff and Zettelmeyer, 2002; Das, Papaioannou and Trebesch, 2012; and IMF, 2013). Here, we first review the most prominent proposal for the global sphere and then, in a second step, the recent proposals for the euro area (see Table 1 in the Appendix for a summary of the main elements of the reviewed proposals and a comparison to our VIPS proposal).

These designs for the handling of sovereign insolvencies have in common that they aim at arrangements which, in future, could cope with unsustainable debt levels. They do not claim to offer advice for an acute debt crisis and the challenge of unsustainable debt in a highly fragile financial environment. For the latter problem, models like the PADRE ("Politically Acceptable Debt Restructuring in the Eurozone”) plan by Pâris and Wyplosz (2014) or the European Debt Redemption Pact as proposed by the German Council of Economic Advisors (2011) can be an option. These or similar strategies are designed as exceptional one-off solutions to overcome the legacy of over-indebtedness. By contrast, insolvency regimes rather aim to establish a permanent institutional setup which would (re-)establish market discipline once and for all, thereby preventing fiscal crises from arising again in the future. One-off approaches to cope with excessive legacy debt could well be combined with the introduction of a permanent insolvency regime but are not the focus of this contribution.

We furthermore limit our survey to those insolvency procedures which are based on negotiations between creditors and sovereign debtors. Hence, we disregard details of sovereign contingent convertible bonds, which would completely automatize restructurings conditional on certain quantified criteria (mainly certain public debt-to-GDP thresholds) as suggested by Barkbu, Eichengreen, and Mody (2012) in a global and Mody (2013) in a European context.

\section{Sovereign Debt Restructuring Mechanism (SDRM)}

A milestone in the debate and the most prominent model so far is the Sovereign Debt Restructuring Mechanism (SDRM) developed by Anne O. Krueger (2002). The SDRM was supposed to be established under the control of the IMF. However, the amendment to the IMF's Articles of Agreement, which had already been accepted by its board of governors, was never implemented (see Gianviti et al., 2010, for a summary on the debate over this proposal).

The proposal is partly based on the existing insolvency procedures for municipalities in the United States (Chapter 9 of the US Bankruptcy Code) arguing that a sovereign insolvency procedure must be designed differently from procedures for private debtors. Most importantly, the carrying out of basic governmental functions must be guaranteed and, moreover, liquidation is no viable alternative in the municipal and sovereign context. 
Krueger (2002) proposes four main elements of an SDRM to warrant equal treatment of all creditors and preserve asset values: First of all and most importantly, she stresses the necessity of majority decisions (including aggregation across debt instruments) to overcome the collective action problem. Second, Krueger calls for a stay on creditor enforcement as well as payment moratoria while negotiations are underway in order to ensure that these negotiations cannot be undermined by legal actions on the part of single creditors. Third, creditor interests must be protected by prohibiting the servicing of any junior claims. Furthermore, the sovereign debtor would have to ensure that it would not conduct any policy which might destroy existing asset values. As an example, Kruger refers to the potentially necessary implementation of capital controls during the time of negotiations in order to prevent capital flight. Fourth, any potential provision of new money during negotiations should be facilitated and incentivized by ensuring that these new credit lines would be senior to all pre-existing debt. Through the implementation of the SDRM, the IMF was to become the main institution for supervising and financing debt restructurings. The transition process towards full implementation did not receive much attention in the SDRM proposal. When designing the SDRM, the focus was on the situation of developing and emerging countries, where the perspective of debt restructuring is less sensitive for global systemic stability than in the case of euro area countries.

By its nature, the SDRM does not take into account the specific European conditions. Nevertheless, many proposals for the European context including VIPS refer to original ideas of the SDRM. All of these "European" models share the common understanding that some kind of procedure for sovereign insolvency is an indispensable element for the euro area architecture. In the absence of any procedure, the newly established system of liquidity assistance through the ESM and the European Central Bank is at risk to degenerate into a system of permanent transfers with substantial disincentives for prudent fiscal behaviour. Naturally, the earlier proposals could have been more creative with respect to institution building while the more recent ones then took newly established institutions like the European Stability Mechanism (ESM) as given and as a building block for an insolvency procedure.

\section{European Monetary Fund (EMF)}

Gros and Mayer (2010) propose the establishment of a European Monetary Fund (EMF) which is supposed to provide conditional guarantees or loans to countries in need and manage a potential restructuring of the sovereign debt in question. Euro countries would capitalize the fund through weighted contributions which increase with the debt- and deficit-to-GDP levels once they violated the Maastricht criteria. Countries facing illiquidity, in a first step, could obtain EMF funds up to the amount they contributed, if their fiscal adjustment program had previously been approved by the Eurogroup. In a second step, that is in case the country 
would be in need of further funding, it could call on more funds, if it agreed to a customized adjustment program supervised by the European Commission (EC) and the Eurogroup.

In case none of the liquidity aid measures was effective, the proposal would allow for the restructuring of sovereign debt. The haircut should reduce the debt level to the Maastricht level of $60 \%$ of GDP. The remaining debt would be guaranteed by exchanging national debt against claims on the EMF, which would follow the construction of Brady bonds and which would credibly limit the losses of investors.

The proposal does not suggest specific precautions against the hold-out problem and litigation. It does not refer to the transition problem, either. However, restructuring with the help of the EMF could only take place in the future, i.e. once the members' contributions have capitalized the funds of the EMF to a sufficient degree.

\section{European Crisis Resolution Mechanism (ECRM)}

The European Crisis Resolution Mechanism (ECRM) proposed in 2010 (Gianviti et al., 2010) has much in common with the SDRM but adapts it to European requirements. It consists of four main elements: First, euro area members would have to agree on a procedure to initiate negotiations between creditors and the debtor country. As Krueger states in her SDRMproposal, only the debtor country itself should be able to launch negotiations, which in turn would lead to a moratorium of payments and a stay on any ongoing litigation until the negotiations were to be concluded. Second, the decisions made by a qualified majority of the capital (aggregated across all debt issues in question) would be binding for all creditors. Third, negotiations should be supervised or moderated by a politically independent judicial body. The authors propose a newly created chamber at the European Court of Justice for this "first body". The "second body" would provide analytical and financial assistance. These responsibilities could be taken up by the European Commission for the analytical part and a permanent version of the European Financial Stability Facility (EFSF) for the financial assistance (which would now be the ESM). The ECRM-proposal does not contain any detailed discussion about the extent of restructurings but wants to limit the mechanism to cases where debt has reached a "truly unsustainable" level. Furthermore, the ECRM does not pay any attention to the challenges of transition towards the new regime, either.

\section{EEAG-Proposal for a New Crisis Mechanism for the Euro Area}

In 2011, the EEAG (European Economic Advisory Group, 2011) suggested a New Crisis Mechanism for the Euro Area. As the establishment of the ESM had already been under way at the time, the EEAG sees the ESM as the central institution to provide rescue funds and su- 
pervise fiscal adjustment programs. Their proposal of a three-stage procedure for Eurozone members in financial distress refers to different degrees of crises.

In case of (short-term) "illiquidity" - i.e. in the expectation that a country will be able to refinance itself at acceptable conditions in the near future - a euro area member country should be supported by means of short-term loans with a maximum maturity of two years provided by the ESM. The maximum volume should only cover a deficit that is in line with the Maastricht criteria and the country would have to undergo fiscal reforms in order to balance its budget. The loans should be senior to any commercial claims and they should be collateralized by marketable state property, such that these loans would not end up being outright transfers. After having received two years of fiscal aid, the country would not be eligible anymore for assistance throughout the following five years. Should it nevertheless need new funds, it would have to declare "pending insolvency" and thereby would reach the next step.

In case of "pending insolvency", the authors first rely on a market solution. However, in order to make this solution viable, all bonds should contain CACs with aggregation rules in order to overcome the collective action problem (which is why they push for a prompt implementation of CACs). The country would have to negotiate a debt restructuring program with its private creditors within a limited negotiation period of two months, during which the ESM finances necessary governmental functions. In case no agreement could be reached, the ESM, the ECB and the IMF would be called into the negotiation process, which may take another two months. This time, however, there would be an automatic haircut in the nominal value of the bond. Only the size of the haircut would be subject to negotiation: It should, however, amount to at least $20 \%$ and at most $50 \%$ of the debt affected. The actual haircut would be based on the discount at which the bonds were traded on the secondary market during the two previous months. Just like Gros and Mayer (2010), the EEAG advocates Brady bond-type guarantees by the ESM of up to $80 \%$ of the new nominal value. The maximum exposure of the ESM should, however, amount to only half of the Maastricht debt ratio, i.e. to 30\% of GDP.

In the face of "actual insolvency", i.e. if the country was still not able to refinance its debt on the market at acceptable conditions after a three year adjustment period, it would have to declare an outright debt moratorium for all of its outstanding debt and renegotiate all outstanding private debt. At this stage, the ESM would no longer provide financial assistance. To be precise, the ESM would only provide guaranteed replacement bonds for another three years and under strict compatibility with the Maastricht rules, if previous negotiations were successful.

Details of a transition period are not specified in the proposal. However, the proposal acknowledges the fact that the banking sector may still not be able to absorb large debt reductions for the time being. 


\section{European Sovereign Debt Restructuring Regime (ESDRR)}

The European Sovereign Debt Restructuring Regime (ESDRR) suggested by the Committee on International Economic Policy and Reform (2013) takes advantage of the newly implemented institutional framework of the euro area and the creation of the permanent ESM. Unlike earlier designs it contains well elaborated legal details and precautions against holdoutinvestors. The authors suggest defining the new procedure through an (already preformulated) ESM Treaty change and assigning a central role to the restructuring procedure including liquidity aid by the ESM.

Countries with a debt-to-GDP ratio of up to 60\% (i.e. those in line with the Maastricht criteria) which were to face illiquidity would receive unconditional liquidity aid from the ESM. Those countries with a debt-to-GDP ratio of $60-90 \%$ would receive conditional funding and would quasi-automatically have to restructure their debt, if the debt sustainability analysis suggested outright insolvency. Countries facing illiquidity/insolvency and having a debt-toGDP ratio of over $90 \%$ would receive funding only after a prior (automatic) restructuring had taken place. Any restructuring should result in a debt-to-GDP ratio below 90\%.

The ESM Treaty change would offer reliable protection against holdouts by granting the assets and revenue streams of ESM program countries immunity from judicial processes as it had been recommended before (Krueger, 2002; Buchheit, Gulati und Tirado, 2013). Furthermore the treaty change would comprise a supermajority rule according to which a $75 \%$ consent of bondholders' capital aggregated across all issues would be a condition for an ESM endorsed restructuring.

Compared to preceding proposals, the ESDRR has been developed with full awareness of the transition problem. The authors expect that, in the short run, their mechanism would trigger immediate instability and, therefore explicitly consider their model to be a mere long-term solution. A precondition for its full implementation is that all participating countries would have reduced their debt levels to a figure well below the upper threshold (of 90\% of debt-toGDP). To tackle the problem of high legacy debt, the authors recommend to apply strategies like the European Debt Redemption Pact as proposed by the German Council of Economic Advisors (2011) or the PADRE plan by Pâris and Wyplosz (2014), which are both one-time mechanisms of debt restructurings that could achieve lower debt levels for euro area countries. $^{5}$

The ESDRR, with its detailed legal provisions and the mentioned awareness of the transition problem, advances the literature. However, it does not yet offer a strategy on how to cope

\footnotetext{
${ }^{5}$ The employment of the "Politically Acceptable Debt Restructuring in the Eurozone (PADRE)" as a bridge has only been brought into play recently by Beatrice Weder di Mauro, who was one of the lead authors of the ESDRR (Weder di Mauro, 2014).
} 
with time-inconsistency problems, which arise due to the postponement of the reform up to an uncertain date.

\section{VIPS: liquidity provision and insolvency procedure}

VIPS shares the understanding of the proposals described above that, under the conditions of EMU, a defined insolvency procedure is superior to reliance on ad hoc negotiations. It furthermore follows the assessment in the ESDRR proposal (also put forward by Mody, 2013) that the establishment of any insolvency procedure is a risky phase. The financial environment in the euro area remains fragile, as the situation is still shaped by high public debt levels, a heavy exposure of (weak) European banks to their governments' debt and a limited growth potential of the highly indebted economies. In such an environment, a sudden regime change could be seen as a signal for an imminent comprehensive debt restructuring and trigger a new acute crisis.

VIPS tackles this difficulty through lagged implementation: The details of an insolvency procedure are defined today but the procedure will only become effective "in the long run". To this end, VIPS comprises two components: first, a design of a sovereign insolvency procedure which is to be established in the future and, second, an explicit transition path, the "VIPS bridge”, into the "long-run" stage. In this section, we start with the description of the ultimate regime and describe the bridge in the next section.

When designing an insolvency procedure for sovereigns the following fundamental decisions have to be taken: The procedure must comprise a trigger which defines the conditions under which the procedure is activated. It must define rules and set up institutions for the subsequent negotiations comprising the provision of liquidity in the negotiation phase. Specifically, the procedure should define how a decision on a haircut is to be taken and whether quantitative criteria can be defined to determine the extent of a debt restructuring. Furthermore, the insolvency procedure must credibly address the holdout problem and minimize the risk of lengthy and costly litigation. The VIPS insolvency procedure tackles these issues as follows (see Figure 1): 
Figure 1: VIPS - the long-run insolvency procedure

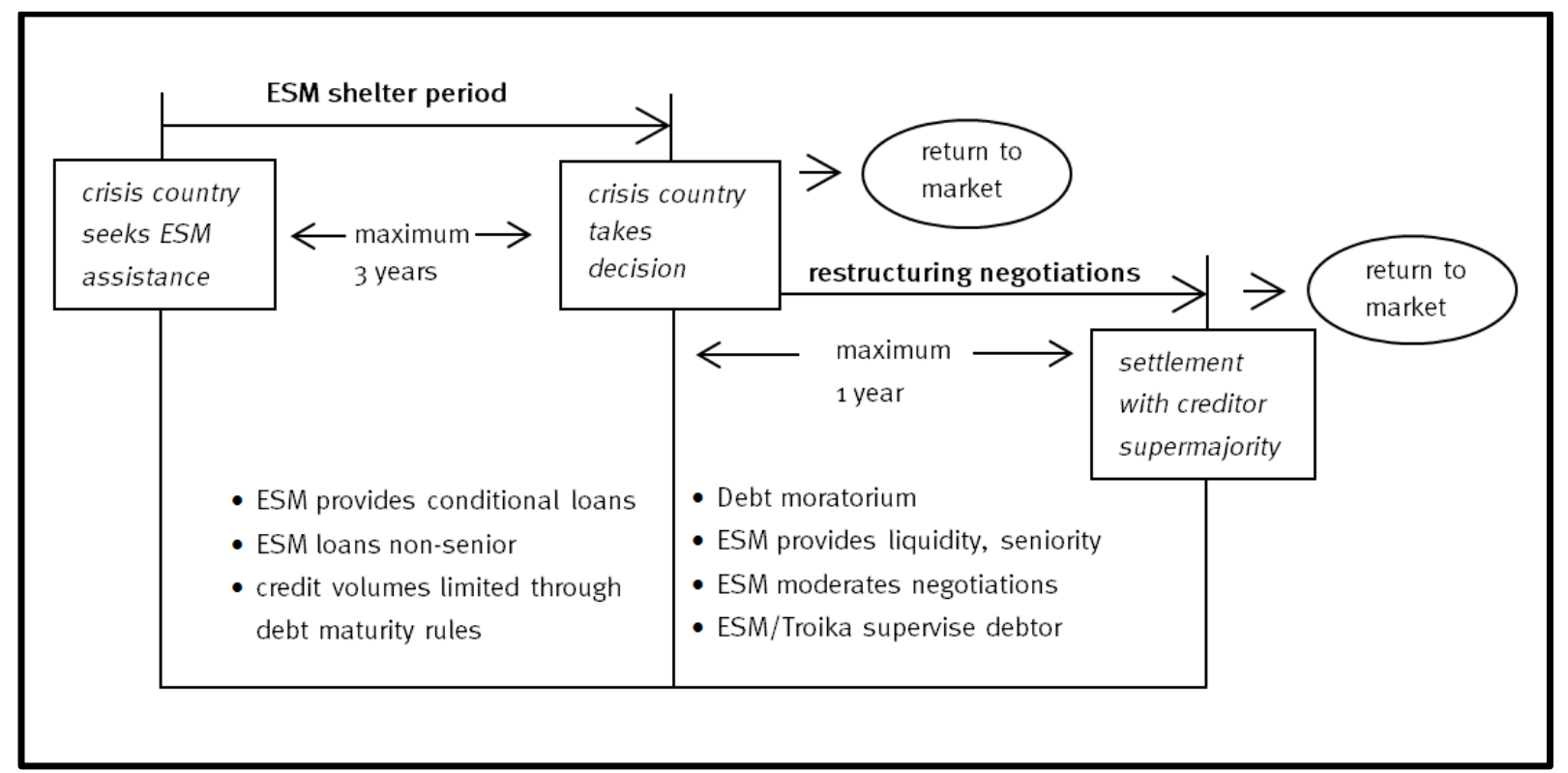

\section{$\underline{\text { Trigger }}$}

VIPS defines a trigger for the insolvency procedure in combination with modified rules for the provision of emergency liquidity through the European Stability Mechanism (ESM): Any euro area member state could continue to rely on ESM assistance according to the rules as they exist today, i.e. loans conditional on consolidation and reform measures. Furthermore, to prevent excessive and unnecessary use of liquidity assistance, the interest rate at which the ESM provides loans should reflect creditworthiness to some extent: The ESM could e.g. charge a small mark-up over the average interest rate for other euro area countries with similar debt levels, to cover for the risk (see also EEAG, 2011).

A major difference compared to the current situation is that, under the VIPS rules, ESM assistance is strictly limited to a period of three years, the "shelter period". A time limit of that sort has been suggested by Fuest (2011) and is also roughly in line with the EEAG proposal (which suggests two years). It proved to be reasonable in the course of the euro area debt crisis. Three years have been sufficient for a country like Ireland to launch substantial reforms, to leave ESM assistance and to return to the bond markets for new loans. Under the VIPS regime, liquidity assistance by the ESM definitely ends with the shelter period. After that, the debtor country has to choose between returning to the market and initiating the insolvency procedure. If the country does not consider market conditions for new bond issues to be acceptable the only remaining option is to trigger the opening of the procedure with the objective of restructuring its debt. ${ }^{6}$ The scheme would hardly encourage a reckless and "too early"

\footnotetext{
${ }^{6}$ No matter how a sovereign insolvency procedure is designed, it must always be the debtor country which initiates the insolvency procedure. An analogy to private insolvency where the debtor can be forced to declare bank-
} 
use of the insolvency procedure as an easy escape from high debt levels. Conditionality of the ESM's liquidity assistance will indeed prevent any precipitous application for funds because it always comes at the expense of a substantial loss of autonomy. Equally, the defined rules for the (maximum) shelter period would address the converse problem that insolvency procedures are often triggered "too late” (International Monetary Fund, 2013).

The shelter period has several further merits: It prevents short-run market turbulences from forcing an immediate debt restructuring. Thus, it limits the damaging potential of a temporary bad equilibrium driven by market panics. It buys time to pursue a course of consolidation and reforms which makes the crisis country more resilient for returning to the market after three years. Moreover, the shelter period can lead to a higher level of available information on the fundamental situation of the debtor country which will make multiple equilibria less likely and, hence, reduce uncertainty (Morris and Shin, 2001).

The time limit prevents a system designed primarily for liquidity assistance from degenerating into a permanent transfer mechanism. Moreover, the shelter period also helps to clarify the underlying causes for an acute liquidity problem. The theoretical distinction between a situation of panic-driven illiquidity and fundamental insolvency is hard to make in reality. If this decision was based on a simple debt-to-GDP threshold like in other proposals, it would be arbitrary and might provoke premature restructurings. The temporary protection over three years with the VIPS procedure will be highly informative. If a government, in spite of three years of assistance, was unable to return to the market this could be seen as a strong indication for fundamental insolvency.

Finally, the shelter period would reduce the risk of contagion (Fuest, 2011): If the activation of the insolvency procedure for one country is seen as a precedent for other euro countries some time thereafter, these other countries could benefit from the full shelter period themselves. Hence, the occurrence of multiple simultaneous restructurings and the resulting massive stress for financial stability could be avoided.

\section{Negotiations}

In the VIPS design, the ESM is the institution responsible to moderate negotiations between the debtor country and the creditors' representatives (which is largely in line with the ESDRR proposal). For that purpose, the ESM establishes and heads a committee comprised of representatives from the debtor country and the group of creditors. The ESM must have veto power in all restructuring decisions since its own loans from the shelter period are also at stake.

ruptcy when total liabilities exceed total assets is not applicable. The value of assets is unobservable for sovereign creditors and externally enforced liquidation of assets is inconsistent with principles of country sovereignty (Gianviti et al., 2010). 
Through the ESM the interests of all guarantors (all euro member states) are represented. The ESM may rely for all negotiations and underlying analyses on the support of the "Troika" (European Central Bank, European Commission and International Monetary Fund) as it does today. A continuing involvement of the International Monetary Fund is no requirement for the procedure but may be desirable due to the Fund's expertise. Here, the VIPS design is open for a differentiated institutional structure along the lines of the ECRM proposal which envisages different bodies. While the ESM is the body for the provision of financial assistance and is also the natural candidate to moderate negotiations, ECB and European Commission would be natural candidates to take up the analytical responsibility.

The start of the procedure has the following consequences, which correspond to the main elements of insolvency procedures like the SDRM proposal with the difference that the ESM steps in for the IMF in the SDRM blueprint:

- With the start of negotiations an immediate moratorium on the debtor country's debt service takes effect. Exceptions leading to privileges for certain groups of creditors have to be limited to a minimum (e.g. multilateral lending) in order to protect the interests of the collective of creditors.

- During the ongoing procedure any sequestration against the debtor is impermissible.

- The ESM (possibly assisted by the Troika) is responsible for the supervision of the debtor country in order to prevent it from impairing the value of its assets.

- During the negotiation phase, the ESM provides the liquidity which is necessary to guarantee basic governmental functions. The extent of this intermediate financing is defined in a bilateral agreement between the ESM and the debtor country. The maximum duration of this liquidity assistance is twelve months, which, consequently, is also the maximum time span restructuring negotiations may last.

\section{Extent of restructuring}

A predefined mechanical formula for the extent of a haircut is neither realistic nor conceptually convincing. Restructuring negotiations are subject to a complicated trade-off: A too modest debt relief may prevent the debtor country from returning to the bond market. And a too generous haircut would unduly impair the interests of the creditors. During the negotiations, it is the responsibility of the ESM (with the assistance of the Troika) to strike a balance between these two extremes and take account of the economic conditions of each single case.

However, an insolvency procedure can offer a more effective expectation anchor, if it includes a rule which indicates the possible maximum loss. Similar to the EMF proposal the following rule should be enshrined in the VIPS procedure: Under no circumstances should the debt settlement push the debt-to-GDP ratio below the Maastricht reference value of $60 \%$. Haircuts which leave the subsequent debt levels above $60 \%$ should remain possible, if the 
debtor country - for example due to a favourable growth perspective or high assets - is deemed to be solvent with higher debt levels. ${ }^{7}$ Linking VIPS to the Maastricht debt-to-GDP reference value would not only stabilize expectations of the maximum loss in case of sovereign insolvency. It would also increase sensitivity for risk premia and increasing debt levels, in particular for levels exceeding the $60 \%$ limit. Market discipline and the reformed Stability and Growth Pact would then both consistently sanction debt levels above that limit.

ESM loans from the shelter period have to be included into the debt restructuring, which is a fundamental difference compared to earlier proposals like the ESDRR or the EEAG proposal. We regard this taxpayer risk exposure as unavoidable. A preferred creditor status for ESM loans provided over the shelter period would damage the stabilization chances of that construction. In case of seniority of ESM claims, the quality of private loans to a crisis country would continuously deteriorate with the increasing share of ESM loans. A similar problem occurred with the implicit seniority of Greek bonds purchased by the ECB since 2010 (which actually did not take part in the PSI in 2012, see Mody, 2013). VIPS' shelter period can only fulfil its stabilization and diagnostic function, if ESM lending within this phase were not privileged compared to new loans from the private sector. The potential losses for the ESM (and, hence, taxpayers) should, however, be limited by appropriate rules on the maturity structure of government bonds which would limit the liquidity needs within the shelter period (see section 5).

The waiver for preferential treatment of ESM loans must only be ensured for the loans from the shelter period but not for the intermediate liquidity provided subsequently during the restructuring negotiations. These new loans should, in fact, have a preferred creditor status as they are provided only after the insolvency procedure has already been triggered and it therefore has become obvious that the crisis country does not suffer from a mere liquidity crisis.

The simultaneous role of the ESM as a lender, moderator and veto player in the restructuring negotiations may give rise to conflicts of interest. As a lender, the ESM (and its guarantors, the euro member countries) has a self-interest to limit its losses and to strive for a (too) moderate haircut. The more independent analytical assistance from the Troika may alleviate but hardly fully overcome these incentives. Also the experience with Greece points to the potential relevance of this conflict, where public creditors shy away from a second debt restructuring although the high and further rising Greek debt-to-GDP level indicates insolvency. How-

\footnotetext{
${ }^{7}$ Here, VIPS diverges from the Gros and Mayer (2010) proposal who suggested cutting back debt levels to 60\% in any case or the ESDRR which quantifies the target post-restructuring debt level at 60-90\%. Automatisms of that kind would be too mechanical and problematic given the legitimate protection of investors against too far reaching cuts. The assumption underlying the one sided $60 \%$ limit is that any euro area country would be solvent with a public debt level of $60 \%$. We regard this assumption as plausible in the long-run VIPS scenario in which private bank debt, due to a functioning banking union, is a much weaker threat for the stability of public finances than currently.
} 
ever, the rules created by VIPS would address this problem. A too moderate debt relief clearly failing to deliver a sustainable debt situation would impede a return to the bond market. Moreover, according to VIPS rules, ESM liquidity provision beyond the shelter period (plus 12 months interim financing) does not exist. Specifically, the crisis country should not be allowed to apply for continued or renewed ESM financing for a pre-specified number of years. For example, the European Economic Advisory Group (2011) proposes an analogous minimum break of five years. In this setting, an insufficient haircut would provoke nothing but an unorderly default of the crisis country with all its uncertainties. This perspective implies a strong incentive for the ESM and the national governments of the euro area to agree on a sufficiently far reaching extent of debt relief.

\section{$\underline{\text { Precautions against holdout-investors and litigation }}$}

VIPS minimizes the risks and uncertainties from lengthy legal fights with holdout creditors by installing two precautions: first, the obligatory use of refined aggregation rules as an element in euro area CACs and, second, an adjustment of the ESM Treaty granting immunity of program countries' assets from any creditor attachment, thereby following the exact route of the ESDRR strategy.

Since 2013, the ESM Treaty mandates CACs for all newly issued government bonds of euro countries (Benzler et al., 2012; Buchheit, Gulati und Tirado, 2013). These clauses define majorities of bond holders able to take binding restructuring decisions for all bond holders with the intention to preclude holdout-strategies. Standard CACs only define majorities for the individual bond issue and, therefore, are hardly effective in this regard. This merely brings the holdout problem to a different level instead of solving it once and for all. Even with limited capital, holdout investors could still buy blocking minorities of single smaller bond issues and successfully proceed with their strategy. Aggregation clauses can thwart potential holdouts since they define majorities across all bond issues whose decisions are binding for each single issue. Current euro area-CACs comprise aggregation features which would hardly contain holdouts. For an overall binding decision, not only a quorum of $75 \%$ of capital invested in the aggregate but also an additional majority of at least two thirds in each individual bond have to be achieved (Zettelmeyer, Trebesch und Gulati, 2013). With these weak features vulture funds could still easily accumulate bond volumes amounting to a blocking minority for a single issue.

For that reason, CACs as prescribed in the ESM Treaty must be revised through a stronger aggregation principle. Bond-by-bond quorums must be deleted completely with the aggregate quorum being the necessary and sufficient condition for binding creditor decisions, the aggregate quorum should be reduced to two thirds of the capital invested. 
The risk that lawsuits against a restructuring can be successful at courts in third countries (like the US) or would at least imply lengthy legal uncertainties can be addressed through a further adjustment of the ESM Treaty (Buchheit, Gulati und Tirado, 2013; Committee on International Economic Policy and Reform, 2013). A new provision should grant immunity from creditor attachments to the assets of euro area countries which participate in an ESM-supported adjustment program. ${ }^{8}$ Such an amendment would be sufficient to comprehensively exclude legal risks.

\section{VIPS: the bridge}

VIPS would expose private creditors of euro countries to significant potential losses, if these countries end up in insolvency. Hence, VIPS' prompt and full implementation would possibly cause concerns about the quality of euro area government bonds in general. This regime change could induce new turbulences and market panics which might lead to a new acute debt crisis. Therefore, VIPS' full effectiveness requires an environment which is resilient and characterized in the following way:

- The European banking union needs to be established and fully operational. This implies, for instance, that national and European resolution funds are sufficiently capitalized. Banks are protected through higher equity ratios and a liability cascade clearly defines the hierarchy of liabilities of shareholders and creditors in case of failing banks.

- Bank claims against sovereign debtors do no longer benefit from regulatory privileges. Claims vis-à-vis sovereigns have to be backed-up with equity just like claims vis-à-vis private debtors (of comparable creditworthiness) and are subject to the same rules in order to prevent risk concentration (like upper limits on large value credits). European banks have adjusted their lending to these new rules and, consequently, their balance sheets are no longer characterized by a massive exposure to their respective home country or other euro area countries.

- Fiscal recovery has made considerable progress. Debt-to-GDP-ratios are down substantially compared to crisis levels and reach maximum values in the range between $60 \%$ and $100 \%$ for the most compromised countries.

- The remaining public debt is financed with long average maturities. As a result, the annual refinancing need of euro countries is moderate, which reduces the risk of a bond market run and self-enforcing liquidity crises. At the same time, the long-run debt structure limits the maximum credit volumes required, if ESM financing is needed for the three year shelter period.

\footnotetext{
${ }^{8}$ See Buchheit, Gulati and and Tirado (2013, p. 8) for a precise suggestion for the wording of a respective new article taken up by the Committee on International Economic Policy and Reform (2013, p. 40).
} 
- A significant part of (but not necessarily the total) volume of debt would need to be penetrated by the above mentioned refined CACs with a stronger aggregation principle in order to prevent hold-out strategies on single bonds issues.

In such an environment, the conditionality of ESM liquidity funding as well as the maximum duration of the shelter period would indeed be credible because systemic risks of a sovereign debt restructuring at the end of the shelter period is significantly reduced.

Obviously, the current situation is still far from being shaped by such resilience. Under the fragile current conditions, the insolvency of a medium-sized or even small euro area country would imply substantial systemic risks even though VIPS includes precautions like the shelter period. However, delaying any reform and waiting for better times is no option, as the lacking perspective on how to deal with an insolvent euro member country is a risk factor in itself. VIPS' solution for that dilemma is based on the principle of lagged implementation through the construction of a transition path, the "VIPS bridge". Other concepts lack this bridge. Even the ESDRR, which pays attention to the transition problem, simply delays any reform until the legacy debt problem has been dealt with (Committee on International Economic Policy and Reform, 2013) - a solution which is obviously confronted with time inconsistency problems and lacking credibility.

By contrast, VIPS pays close attention to the time inconsistency problem. The VIPS bridge fosters immediate irreversibility by setting the course for the new regime already today. Such a model of lagged implementation creates precedents for the future and makes use of the current crisis-related opportunity to implement reforms (Buchanan, 1994) without destabilizing the currently still fragile financial situation.

A critical condition for the success of lagged implementation is the irreversibility of the reform decision. With the approaching deadline for full effectiveness of the pre-announced new regime, resistance could grow and finally impede full implementation. Against the backdrop of this strategic difficulty, VIPS offers the following guarantees as a bridge into the long-run solution (see Figure 2): 


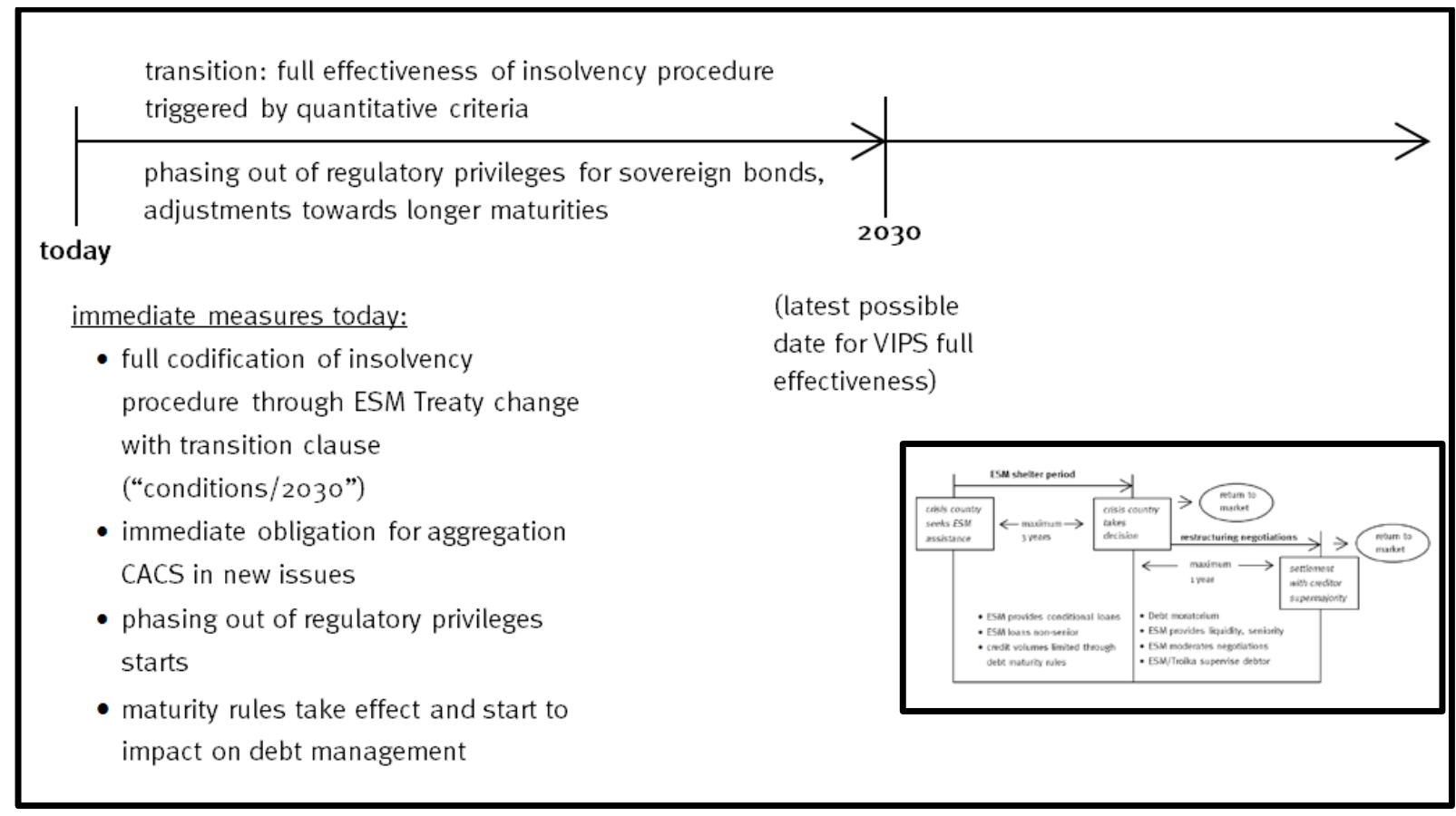

The insolvency procedure as described in the preceding section would be codified in all details through an amendment of the ESM Treaty already today. In this amendment, one article stipulates that this defined insolvency procedure only takes effect on a pre-specified date. Hence the phasing-in of the new regime would be determined through international law and the unanimity requirement for any treaty changes offers protection against later reversals.

The date for full implementation is to be defined in the following way: The VIPS insolvency regime becomes fully effective no later than a fixed date (e.g. starting with the year 2030) or earlier, if the average euro area government debt-to-GDP ratio has fallen below a critical value (e.g. 80\% from currently 96\%) and the European Resolution Fund for banks has reached a certain well-defined capitalization level. Further quantifiable criteria relating, e.g., to bank capitalization could be added. It is crucial that such conditions are quantifiable without any significant margin of interpretation.

The fixed date defines the latest possible date for the regime change. It has the function of a fall back condition in case politicians would try to strategically delay the fulfilment of the quantifiable criteria. A criteria-guided effectiveness of the insolvency procedure clearly is the preferable scenario. It would imply that the full VIPS implementation occurs in a friendly financial and fiscal environment. Times in which public debt levels fall tend to be times in which government bond markets are stable. Compared to that, a fixed pre-determined date implies large uncertainty on the specific market situation and, as a consequence, a larger risk of destabilization. Nevertheless, the fixed date is an unavoidable fall back condition to safeguard the ultimate irreversibility of the regime change against political criteria manipulations. 
Additionally, both politicians and investors know exactly when the regime change will come eventually. Therefore they then can adapt their expectations and act accordingly.

The transitory phase of the ESM Treaty change and the final full effectiveness of VIPS in the future must not be misunderstood as a phase during which restructurings of sovereign debt are precluded. Certainly, ad hoc restructurings as in the case of Greece remain an available option throughout the transition path, which is defined by the VIPS bridge. The ESM Treaty change must avoid any contents which could be (mistakenly) seen as a signal for guarantees against restructurings in that transitory phase. ${ }^{9}$ However, the ultimate frameworks of VIPS can only be fully available with the end of the transitory phase.

The immediate ESM Treaty change would be an important but not the only precaution against the time inconsistency problem. Several accompanying measures would emphasize the irreversibility of the transition path starting today.

With immediate effectiveness, the ESM Treaty change would define a more convincing aggregation clause as an obligatory element of euro area CACs for all government bonds issued in the future. The fact, that the prescription of CACs through the ESM Treaty was possible even in the middle of the acute phase of the debt crisis indicates that their modification and refinement would hardly imply severe risks for bond market stability. Nevertheless, this reform would create important preconditions for the future insolvency procedure.

The ESM Treaty change should also include precise prescriptions for the maturity structure of new government debt issues. Even though long maturities are in the self-interest of each euro country there is a justification for externally imposed constraints. Short average maturities increase the vulnerability for liquidity crises. For VIPS, they imply a larger credit requirement over the shelter period and, as a consequence, a larger credit risk for the partner countries. Rules on minimum maturities are a natural reaction to counter the disincentives originating from these fiscal externalities. Furthermore, higher interest rates related to longer maturities may also have a disciplining effect with respect to the problem of over-borrowing. ${ }^{10}$

The transitory phase towards full VIPS effectiveness should go hand in hand with the phasing-out of regulatory privileges for sovereign debtors with respect to bank and insurance capital requirements. The latter faces challenges similar to the immediate effectiveness of an insolvency procedure. An abrupt change in the regulatory regime could lead to new downward

\footnotetext{
${ }^{9}$ In this regard, no grandfathering clauses for bonds issued before the full effectiveness of the insolvency procedure must be granted. Once the final VIPS provisions are fully effective all future restructurings would relate to all outstanding bonds.

${ }^{10}$ Contingent maturity extension defined in bond contracts could be a substitute for maturity regulations. Deutsche Bundesbank (2008, p. 73), for example, favors an automatic maturity extension of three years, if a country receives ESM funding. This would confine the risks borne by the ESM.
} 
spirals at government bond markets. Nonetheless, the cautious phasing-out of these privileges with a long transitory period is possible and could be initiated immediately.

Thus, the credibility of the VIPS bridge is firmly grounded on two pillars: first, the precise determination of full VIPS effectiveness through a change in the ESM Treaty which employs the commitment devices of international law, and, second, immediate reforms which already launch the (quasi-) irreversible regime change.

\section{Conclusions}

VIPS is designed under the assumption that no agreement on a common centralized fiscal policy regime, backed up by a transfer union, can be reached in the euro area. Therefore it proposes a bridge towards a more consistent institutional architecture based on the principles of national budgetary autonomy.

Particularly, it offers a model to deal with insolvent member countries in the future while paying attention to the current fragility. It avoids any abrupt institutional change at present, but does not simply delay reforms for an indeterminate duration. It makes use of the reform momentum of the current crisis to initiate a cautious but steady and irreversible reform transition.

Of course, chances for the model's political realization are uncertain. The current temporary calming of the situation may already dampen the sense of urgency and therefore the readiness for reforms. Governments are always reluctant to accept reforms which would increase financial market constraints for their borrowing. On the other hand, VIPS promotes a responsible use of deficit finance: for countries with sustainable debt levels it offers reliable protection against the risks of liquidity crises. Furthermore, its construction is fully consistent with the new euro area fiscal governance (reformed Stability and Growth Pact and the Fiscal Compact). All of these innovations stress the Maastricht 60\%-objective for the debt-to-GDP level and, under VIPS, no restructuring threat exists for countries which respect that objective. Hence, political resistance against VIPS is inconsistent assuming that governments take the recent reforms of fiscal rules seriously. Apart from that, the lagged implementation inherent in VIPS is helpful to overcome potential political resistance: By accepting VIPS and the VIPS bridge, today's governments would not tie their own hands but their (distant) successors. In addition, they would have at least some incentives to abstract from the current, narrow interests of their own countries and place more emphasis on general stability issues. This should help to foster consent.

Without a clear insolvency procedure, the euro area would continue becoming a hardly functional hybrid: A large degree of national budgetary autonomy combined with collective guarantees of de facto unlimited extent provided by fiscal and monetary authorities. This inconsistent institutional setting would imply massive disincentives and substantial risks for financial stability and, as the ultimate consequence, political acceptance of European integration. 


\section{References}

Barkbu, B., B. Eichengreen and A. Mody (2012), Financial Crises and the multilateral response: What the historical record shows, Journal of International Economics, 88(2), 422-435.

Benzler, M., D. Dunnigan, E. Green, S. James, T. Lockley, J. Machin, S. Maerker, T. Morris und Z. Deborah (2012), Collective Action Clauses for the Euro Area, Clifford Chance Briefing Note.

Buchanan, J.M. (1994), Lagged Implementation as an Element in Constitutional Strategy, European Journal of Political Economy, 10(1), 11-26.

Buchheit, L.C., G.M. Gulati und I. Tirado (2013), The Problem of Holdout Creditors in Eurozone Sovereign Debt Restructurings, Draft, 01/22/2013.

Bundesverfassungsgericht (2014), Entscheidung 2 BvR 2728/13, 14. Januar 2014, Karlsruhe.

Burret, Heiko T., Jan Schnellenbach (2014), Implementation of the Fiscal Compact in the Euro Area Member States, German Council of Economic Experts, Working Paper, 08/2013, partly updated in January 2014.

Buti, Marco and Nicolas Carnot (2012), The EMU Debt Crisis: Early Lessons and Reforms, Journal of Common Market Studies, 50 (6), 899-911.

Committee on International Economic Policy and Reform (2013), Revisiting Sovereign Bankruptcy, (Lead Authors: Lee C. Buchheit, Anna Gelpern, Mitu Gulati, Ugo Panizza, Beatrice Weder di Mauro, Jeromin Zettelmeyer), Brookings, October 2013.

Das, U.S., M.G. Papaioannou und C. Trebesch (2012), Sovereign Debt Restructuring 19502010: Literature Survey, Data, and Stylized Facts, IMF Working Paper, 12/203.

De Grauwe, P. and Y. Ji (2012), Mispricing of Sovereign Risk and Macroeconomic Stability in the Eurozone, Journal of Common Market Studies, 50(6), 866-880.

Deutsche Bundesbank (2008), Monatsbericht August, Frankfurt.

European Central Bank (2011), The European Stability Mechanism, ECB Monthly Bulletin, Articles, July 2011.

European Central Bank (2012a), A Fiscal Compact for a Stronger Economic and Monetary Union, ECB Monthly Bulletin, Articles, May 2012.

European Central Bank (2012b), Technical features of Outright Monetary Transactions, Press Release, 6 September 2012.

European Commission (2014), Banking Union: Restoring Financial Stability in the Eurozone, Memo/14/294, April 2014. 
European Economic Advisory Group (2011), A New Crisis Mechanism for the Euro Area, The EEAG Report on the European Economy, 71-96, CESifo, Munich.

Fuest, C. (2011), Ein Vorschlag für einen Krisenbewältigungsmechanismus in der Eurozone nach 2013, ifo Schnelldienst, 64(3), 10-14.

German Council of Economic Advisors (2011), Ein Schuldentilgungspakt für Europa, Auszug aus dem Jahresgutachten 2011/12, 109-118.

Gianviti, F., A. O. Krueger, J. Pisani-Ferry, A. Sapir und J. von Hagen (2010), A European Mechanism for Sovereign Debt Restructuring: A Proposal, Bruegel Blueprint Series, Volume X.

Gros, D., and T. Mayer (2010), How to deal with sovereign default in Europe: Create the European Monetary Fund now!, CEPS Policy Brief, 202, Centre for European Policy Studies (CEPS).

Hodson, Dermot (2013), The Eurozone in 2012: 'Whatever It Takes to Preserve the Euro'?, Journal of Common Market Studies, 51, Annual Review, 183-200.

Howarth, David and Lucia Quaglia (forthcoming), The Steep Road to European Banking Union: Constructing the Single Resolution Mechanism, Journal of Common Market Studies.

International Monetary Fund (2013), Sovereign Debt Restructuring - Recent Developments and Implications for the Fund's Legal and Policy Framework, International Monetary Fund (IMF). Washington, DC, April 26.

Krueger, Anne O. (2002), A New Approach to Sovereign Debt Restructuring, International Monetary Fund (IMF), Washington, DC, April.

Mody, A. (2013), Sovereign Debt and its Restructuring Framework in the Euro Area, Bruegel Working Paper, 2013/05.

Morris, Stephen and Hyun Song Shin (2001), Rethinking Multiple Equilibria in Macroeconomic Modeling, in: Ben S. Bernanke and Kenneth Rogoff (eds.), NBER Macroeconomics Annual 2000, Vol. 15, MIT Press, Cambridge, 139-182,

Olivares-Caminal, Rodrigo (2014), The EU Architecture to Avert A Sovereign Debt Crisis, OECD Journal: Financial Market Trends, 2011(2).

Pâris, Pierre, and Charles Wyplosz (2014), Politically Acceptable Debt Restructuring in the Eurozone, Geneva Reports on the World Economy, Special Report 3, International Center for Monetary and Banking Studies (ICMB), Center for Economic Policy Research (CEPR).

Reinhart, Carmen M. and Kenneth S. Rogoff (2008), This Time Is Different: A Panoramic View of Eight Centuries of Financial Crises, Princeton University Press, Princeton. 
Rogoff, Kenneth, and Jeromin Zettelmeyer (2002), Bankruptcy Procedures for Sovereigns: A History of Ideas, 1976-2001, IMF Staff Papers, 49(3), International Monetary Fund (IMF).

Roubini, Nouriel and Brad Setser (2004), Bail-outs or Bail-ins? Responding to Financial Crises in Emerging Market Economies, Peterson Institute for International Economics, 378, October.

Weder di Mauro, Beatrice (2014), Warum die Eurozone eine Insolvenzordnung für Staaten braucht, www.oekonomenstimme.org, 02.04.2014.

Zettelmeyer, J., C. Trebesch und M. Gulati (2013), The Greek Debt Restructuring: An Autopsy, CESifo Working Paper, 4333. 


\section{Appendix - Table 1: Summary of Proposals}

\begin{tabular}{|c|c|c|c|c|c|c|c|c|c|}
\hline $\begin{array}{l}\text { Name of Proposal / } \\
\text { Authors }\end{array}$ & $\begin{array}{c}\text { Regional } \\
\text { context }\end{array}$ & Legal basis & $\begin{array}{c}\text { Key } \\
\text { institution(s) }\end{array}$ & Liquidity provision & $\begin{array}{c}\text { Seniority of } \\
\text { liquidity } \\
\text { provisions }\end{array}$ & $\begin{array}{l}\text { Modalities of trigger of } \\
\text { restructuring }\end{array}$ & $\begin{array}{c}\text { Precaution against } \\
\text { holdouts }\end{array}$ & Extent of restructuring & Transition problem \\
\hline $\begin{array}{l}\text { SDRM } \\
\text { (Sovereign Debt } \\
\text { Restructuring Mech- } \\
\text { anism) } \\
\text { Krueger (2002) }\end{array}$ & Global & $\begin{array}{l}\text { IMF Arti- } \\
\text { cles of } \\
\text { Agreement }\end{array}$ & IMF & $\begin{array}{l}\text { Financing by IMF } \\
\text { conditional on adoption } \\
\text { of economic policy } \\
\text { framework }\end{array}$ & Yes & $\begin{array}{l}\text { Debtor request + ac- } \\
\text { ceptance by qualified } \\
\text { majority of creditors }\end{array}$ & $\begin{array}{l}\text { Qualified majority } \\
\text { restructuring provi- } \\
\text { sions with aggrega- } \\
\text { tion } \\
\text { Payment moratori- } \\
\text { um and stay on all } \\
\text { litigation }\end{array}$ & No details & No details \\
\hline $\begin{array}{l}\text { EMF } \\
\text { (European Monetary } \\
\text { Fund) } \\
\text { Gros and Mayer } \\
\text { (2010) }\end{array}$ & Euro area & EU Treaty & $\begin{array}{l}\text { EMF (European } \\
\text { Monetary Fund), } \\
\text { Surveillance by } \\
\text { European Com- } \\
\text { mission and } \\
\text { Eurogroup }\end{array}$ & $\begin{array}{l}\text { Stage I: EMF guarantees } \\
\text { (up to country's own } \\
\text { contribution) conditional } \\
\text { on fiscal adjustment } \\
\text { program } \\
\text { Stage II: EMF guaran- } \\
\text { tees (above country's } \\
\text { own contribution) condi- } \\
\text { tional on implementation } \\
\text { of tailor-made adjust- } \\
\text { ment program }\end{array}$ & No details & No details & No details & $\begin{array}{l}\text { Haircut should decrease } \\
\text { debt-GDP-level to } 60 \% \text {, } \\
\text { use of Brady-bond-type } \\
\text { EMF bond to guarantee } \\
\text { the remaining claims }\end{array}$ & No details \\
\hline $\begin{array}{l}\text { ECRM } \\
\text { (European Crisis } \\
\text { Resolution Mecha- } \\
\text { nism) } \\
\text { Gianviti et al. (2010) }\end{array}$ & Euro area & EU Treaty & $\begin{array}{l}\text { European Court of } \\
\text { Justice (ECJ), } \\
\text { European Com- } \\
\text { mission (EC), } \\
\text { ESM (permanent } \\
\text { EFSF in original } \\
\text { text) }\end{array}$ & $\begin{array}{l}\text { Short- to medium term } \\
\text { financial aid by ESM } \\
\text { conditional on achieve- } \\
\text { ment of agreement } \\
\text { between debtor and } \\
\text { creditors reestablishing } \\
\text { solvency }\end{array}$ & No details & $\begin{array}{l}\text { ECJ opens procedure } \\
\text { after debtor request + } \\
\text { acceptance by qualified } \\
\text { majority of creditors + } \\
\text { approval of EC }\end{array}$ & $\begin{array}{l}\text { Qualified majority } \\
\text { restructuring provi- } \\
\text { sions with aggrega- } \\
\text { tion } \\
\text { Payment moratori- } \\
\text { um and stay on all } \\
\text { litigation } \\
\text { Dispute resolution } \\
\text { mechanism }\end{array}$ & No details & No details \\
\hline
\end{tabular}




\begin{tabular}{|c|c|c|c|c|c|c|c|c|c|}
\hline $\begin{array}{l}\text { Name of Proposal / } \\
\text { Authors }\end{array}$ & $\begin{array}{c}\text { Regional } \\
\text { context }\end{array}$ & Legal basis & $\begin{array}{c}\text { Key } \\
\text { institution(s) }\end{array}$ & Liquidity provision & $\begin{array}{l}\text { Seniority of } \\
\text { liquidity } \\
\text { provisions }\end{array}$ & $\begin{array}{l}\text { Modalities of trigger of } \\
\text { restructuring }\end{array}$ & $\begin{array}{c}\text { Precaution against } \\
\text { holdouts }\end{array}$ & Extent of restructuring & Transition problem \\
\hline $\begin{array}{l}\text { EEAG-Proposal } \\
\text { (New Crisis Mecha- } \\
\text { nism for the Euro } \\
\text { Area) } \\
\text { European Economic } \\
\text { Advisory Group } \\
\text { (EEAG) (2011) }\end{array}$ & Euro area & $\begin{array}{l}\text { EU Treaty } \\
\text { (ESM) }\end{array}$ & $\begin{array}{l}\text { ESM; Troika } \\
\text { (ESM together } \\
\text { with ECB and } \\
\text { IMF) }\end{array}$ & $\begin{array}{l}\text { Three-step-procedure } \\
\text { (see text for details), } \\
\text { strict time limitations for } \\
\text { liquidity assistance } \\
\text { General rule: Loans and } \\
\text { guarantees may never } \\
\text { surpass } 30 \% \text { of country's } \\
\text { GDP }\end{array}$ & Yes & $\begin{array}{l}\text { Extreme debt level } \\
\text { (120\% debt-GDP) or } \\
\text { liquidity aid after time } \\
\text { limit could not restore } \\
\text { market access. }\end{array}$ & $\begin{array}{l}\text { Modified CACs for } \\
\text { all government } \\
\text { bonds - majority } \\
\text { rule applies to all } \\
\text { bonds maturing at } \\
\text { the same time }\end{array}$ & $\begin{array}{l}\text { Size of haircuts guided } \\
\text { by discounts observed in } \\
\text { markets, use of Brady- } \\
\text { bond-type "replacement } \\
\text { bonds" with EMF guar- } \\
\text { antees for the remaining } \\
\text { claims }\end{array}$ & No details \\
\hline $\begin{array}{l}\text { ESDRR } \\
\text { (European Sovereign } \\
\text { Debt Restructuring } \\
\text { Regime) } \\
\text { Committee on } \\
\text { International Eco- } \\
\text { nomic Policy Reform } \\
\text { (2013) }\end{array}$ & Euro area & $\begin{array}{l}\text { ESM } \\
\text { Treaty }\end{array}$ & ESM & $\begin{array}{l}\text { ESM provides liquidity: } \\
\text { Unconditionally if } \\
\text { debt/GDP < 60\%; } \\
\text { Conditionally if } \\
\text { debt/GDP } 60-90 \% \text {; } \\
\text { only with prior restruc- } \\
\text { turing if debt/GDP > } \\
90 \%\end{array}$ & Yes & $\begin{array}{l}\text { When debt/GDP > 90\% } \\
\text { and liquidity crisis; } \\
\text { when debt/GDP } 60-90 \% \\
\text { if debt sustainability } \\
\text { analysis suggests insol- } \\
\text { vency; } \\
+ \\
\text { Approval by ESM }\end{array}$ & $\begin{array}{l}\text { Immunization of to- } \\
\text { be-restructured debt } \\
\text { Aggregation CACs }\end{array}$ & $\begin{array}{l}\text { Restructuring must result } \\
\text { in debt/GDP }<90 \% \\
\text { (short-term debt subject } \\
\text { to higher haircut) }\end{array}$ & $\begin{array}{l}\text { Treaty change } \\
\text { postponed until } \\
\text { legacy debt problem } \\
\text { has been solved (e.g. } \\
\text { through Debt Re- } \\
\text { demption Pact) }\end{array}$ \\
\hline $\begin{array}{l}\text { VIPS } \\
\text { (Viable Insolvency } \\
\text { Procedure for Sover- } \\
\text { eigns) }\end{array}$ & Euro area & $\begin{array}{l}\text { ESM } \\
\text { Treaty }\end{array}$ & ESM & $\begin{array}{l}\text { ESM provides loans over } \\
\text { 3-year-shelter period } \\
+ \\
\text { liquidity during restruc- } \\
\text { turing negotiations }\end{array}$ & $\begin{array}{l}\text { No during } \\
\text { shelter period } \\
\text { (Yes for } \\
\text { liquidity aid } \\
\text { provided } \\
\text { during re- } \\
\text { structuring } \\
\text { negotiations) }\end{array}$ & $\begin{array}{l}\text { Inability to access mar- } \\
\text { ket after shelter period }\end{array}$ & $\begin{array}{l}\text { Immunization of to- } \\
\text { be-restructured debt } \\
\text { Aggregation CACs }\end{array}$ & $\begin{array}{l}\text { Restructuring would not } \\
\text { decrease debt/GDP to } \\
\text { below } 60 \%\end{array}$ & $\begin{array}{l}\text { Immediate ESM } \\
\text { Treaty change with } \\
\text { transition clause; } \\
\text { VIPS bridge }\end{array}$ \\
\hline
\end{tabular}

